\title{
MENGEMBANGKAN MINAT BACA ANAK USIA DINI MELALUI KEGIATAN LITERASI PERPUSTAKAAN DI PAUD HASANUDDIN MAJEDI BANJARMASIN
}

\author{
Hidayati Desy \\ Akademi Maritim Nusantara Banjarmasin \\ Hidayati_desy@ymail.com
}

\begin{abstract}
Abstrak
Sekolah sebagai salah satu lembaga pendidikan untuk belajar. Sekolah sangat berperan penting dalam bidang pendidikan dan tempat yang paling efektif dalam proses belajar. Pendidikan merupakan hal utama yang dilakukan oleh setiap bangsa untuk mencapai kemajuan. Semakin berkualitas suatu bangsa itu semakin memberikan efek positif bagi kemajuan bangsa dan negara yang merupakan suatu proses dengan tujuan untuk mengembangkan sikap, tingkah laku dan membantu dalam pembentukan karakter serta mencerdaskan setiap individu dengan membaca akan memperoleh berbagai macam informasi. Upaya orang tua akan lebih optimal akan adanya dukungan dari pihak lain, seperti lingkungan keluarga dan lingkungan sekolah. Tujuan yang hendak dicapai dari program ini adalah mengetahui bagaimana cara mengembangkan minat baca anak usia dini melalui kegiatan literasi perpustakaan di PAUD Hasanuddin Majedi Banjarmasin? Sedangkan metode pelaksanaannya dengan bersosialisasi langsung kepada guru PAUD dan anak-anak yang ada di sekolah tersebut, dengan membawa beberapa bahan dasar buku cerita bergambar yang disukai anak-anak. Adapun hasil yang diperoleh adalah Anak yang terbiasa melihat buku dan kebiasaan membaca dari orang tuanya akan membuat mereka gemar membaca. Simpulan dari pengabdian ini diperlukan usaha keras untuk mendorong anak untuk berkenalan dengan perpustakaan dapat dilakukan di rumah melalui pembuatan perpustakaan keluarga.
\end{abstract}

Kata kunci : minat baca, kegiatan literasi, paud hasanuddin Majedi Banjarmasin

\section{Abstract}

School as an educational institution for learning. Schools play an important role in the field of education and are the most effective places in the learning process. Education is the main thing that is done by every nation to achieve progress. The higher the quality of a nation, the more it has a positive effect on the progress of the nation and state, which is a process with the aim of developing attitudes, behavior and helping in character building and educating each individual by reading and getting various kinds of information Parents' efforts will be more optimal with the support of other parties, such as the family environment and the school environment. The objectives of this program are: To find out how to develop reading interest in early childhood through library literacy activities at PAUD Hasanuddin Majedi Banjarmasin. Meanwhile, the implementation method is by socializing directly with the PAUD teachers and the children in the school, by bringing some basic material for picture books that the children like. The results obtained are children who are accustomed to seeing books and reading habits from their parents will make them like reading. The conclusion of this dedication requires a strong effort to encourage children to get acquainted with the library, which can be done at home through the creation of a family library

Keywords: reading interest, literacy activites, paud hasanuddin Majedi Banjarmasin 


\section{PENDAHULUAN}

Masa ini merupakan masa awal pengembangan kemampuan fisik, kognitif, bahasa, moral, dan nilai-nilai agama. Oleh karena itu dibutuhkan kondisi dan stimulasi yang sesuai dengan kebutuhan anak agar pertumbuhan dan perkembangannya tercapai secara optimal. Pada masa perkembangan anak usia dini biasa disebut dengan masa emas atau golden age, masa golden age adalah masa anak usia dini (PAUD) untuk mengeksplorasi hal-hal yang mereka ingin lakukan, senang bermain dan peka terhadap rangsangan sekitar. Di era globalisasi ini banyak orang tua yang kurang memerhatikan perkembangan anak melainkan hanya sebatas memenuhi kebutuhannya, seperti memenuhi segala keinginan anak tetapi tidak memperhatikan dampak negatif yang akan terjadi. Kebanyakan anak zaman sekarang itu lebih suka bermain gadged ketimbang membaca buku. Orangtua punya peran dalam menumbuhkan minat baca anak sejak dini. Melalui keteladanan orang tua untuk membacakan anak buku sebelum tidur, mengajak anak pergi ke toko buku dan membelikannya buku, karena pendidikan itu berawal dari orangtua. Terutama dari ibu karena anak adalah peniru ulung dunia.

Membaca merupakan jantung pendidikan, di zaman sekarang ini tuntutan melek huruf tidak cukup dengan bisa membaca saja tanpa didukung tradisi membaca. Membaca menjadi kebutuhan dan kegiatan sehari-hari setiap manusia. Membaca juga sangat penting dalam kehidupan masyarakat yang semakin kompleks. Setiap kehidupan melibatkan kegiatan membaca sehingga kemampuan membaca merupakan tuntutan realitas kehidupan sehari-hari manusia arena dengan membaca akan memperoleh berbagai macam informasi. Upaya orang tua akan lebih optimal akan adanya dukungan dari pihak lain, seperti lingkungan keluarga dan lingkungan sekolah. Oleh karena itu, masih diperlukan usaha keras untuk mendorong anak untuk berkenalan dengan perpustakaan dapat dilakukan di rumah melalui pembuatan perpustakaan keluarga. Anak yang terbiasa melihat buku dan kebiasaan membaca dari orang tuanya akan membuat mereka gemar membaca. Kebanyakan orang tua sangat antusias dengan adanya kegiatan literasi di sekolah. Hal ini karena kebanyakan berpendapat tentang minat baca itu sangat baik, mendidik, bagus, dan sangat penting. Minat baca tidak hanya ditumbuhkan lewat sekolah saja namun orang tua juga harus ikut serta dengan mendorong anak agar gemar membaca dengan cara orang tua menumbuhkan minat baca yaitu membelikan buku-buku bacaan, atau dengan membelikan alat permainan edukatif supaya belajar sambil bermain, sering membacakan buku cerita, dongeng, dan ada juga yang melatih membaca tulisan yang ada di pinggiran jalan. Dari sekian banyak orang tua berpendapat bahwa anakanaknya menyukai buku bacaan seperti buku yang bergambar, cerita hewan-hewan, majalah anak, buku pengetahuan, fiksi, buku tentang belajar bahasa inggris, buku mendongeng. Kebanyakan orang tua berpendapat anak suka buku bacaan tentang dongeng, kisah-kisah nabi, dan buku yang bergambar seperti buku yang bergambar binatang dan lainnya. Bagaimana cara mengembangkan minat baca anak usia dini melalui kegiatan literasi perpustakaan di PAUD Hasanuddin Majedi Banjarmasin. Dengan manfaat Bagi guru dari sekolah yang bersangkutan, hasil penelitian ini dapat dijadikan semangat untuk menciptakan generasi gemar membaca sejak usia dini dan dapat memotivasi orang tua agar menciptakan atau menumbuhkan minat baca sejak usia dini. Sehingga menjadi sumbangan pemikiran bagi pembaca, pendidik dan calon pendidik, sekaligus menambah pengalaman dan wawasan baru sebagai wadah untuk mengembangkan pengetahuan cakrawala berfikir khususnya dalam bidang pendidikan. 


\section{Minat Baca}

Pengertian Minat Baca secara sederhana minat berarti kecenderungan dan kegairahan yang tinggi atau keinginan yang besar terhadap sesuatu. Minat dipahami dan dipakai oleh orang selama ini dapat mempengaruhi kualitas hasil belajar siswa.

1. Dalam hal ini tentu saja seseorang yang menaruh minat pada suatu bidang akan lebih mudah mempelajari bidang tersebut. Sekalipun seseorang itu mampu mempelajari sesuatu, tetapi bila tidak mempunyai minat ia tidak akan bisa mengikuti proses belajar.

2. Minat anak dapat timbul dari berbagai sumber antara lain perkembangan instink, funsi-fungsi intelektual, pengaruh lingkungan, pengalaman, kebiasaan dan pendidikan. Oleh karena itu, minat seseorang harus dibina dan diarahkan agar tercapainya tujuan yang diinginkan, khususnya dalam pembelajaran. Untuk meningkatkan minat seseorang, para ahli pendidikan berpendapat bahwa cara yang paling efektif untuk meningkatkan minat adalah dengan memanfaatkan minat yang telah ada pada siswa. Misalnya, siswa berminat dengan balap mobil, sebelum mengajarkan materi percepatan perlu menceritakan sedikit mengenai balap mobil yang sedang berlangsung, baru sedikit demi sedikit diarahkan ke materi pelajaran yang sesungguhnya.Selain itu juga dapat dengan membentuk minat-minat.

\section{Ciri-ciri Minat Baca}

Menurut Hurlock yang dikutip oleh Galuh Wicaksana ciri-ciri pertumbuhan dan perkembangan minat pada anak sebagai berikut:

1. Minat tumbuh bersama dengan perkembangan fisik dan mental

2. Minat tergantung pada kesiapan dan kematangan anak

3. Minat bergantung pada kesempatan belajar

4. Pengaruh budaya

5. Minat berkaitan dengan emosional.

6. Menurut Syaiful Rijal yang dikutip oleh Zaen mengemukakan bahwa seorang anak yang mempunyai minat baca tinggi mempunyai ciri-ciri sebagai berikut:

7. Senantiasa berkeinginan untuk membaca

8. Senantiasa bersemangat saat membaca

9. Mempunyai kebiasaan dan kontinuitas dalam membaca

10. Memanfaatkan setiap peluang waktu dengan membaca

11. Memiliki buku bacaan

12. Mencari bahan bacaan, baik di perpustakaan maupun di tempat lain

13. Memiliki tujuan ketika membaca

14. Mencatat atau menandai hal penting dalam membaca

15. Memiliki kesadaran bahwa membaca berarti telah belajar

16. Mendiskusikan hasil bacaan

\section{Tujuan Minat Baca}

Berikut ini beberapa tujuan aktivitas membaca yaitu :

1. Membaca merupakan suatu kesenangan tidak melibatkan suatu pemikiran yang rumit.

2. Membaca untuk meningkatkan pengetahuan dan wawasan.

3. Membaca untuk dapat melakukan suatu pekerjaan atau profesi. Menurut ahli membaca Steve Stahl yang dikutif oleh Jhon W. Santrock tujuan intruksional membaca seharusnya dapat membantu murid untuk: Mengenali kata secara otomatis, 
memahami teks, termotivasi untuk membaca, dan mengapresiasi bacaan.

\section{Tahapan Membaca}

Untuk mendapatkan hasil membaca yang diinginkan seperti tujuan membaca di atas diperlukan beberapa tahapan perkembangan membaca, seperti yang diungkapkan oleh Harris yang dikutip oleh Mercer ada lima tahapan membaca, yaitu:

1. Kesiapan membaca

2. Membaca permulaan

3. Keterampilan membaca cepat

4. Membaca luas

5. Membaca yang sesungguhnya.

\section{Kebiasaan-kebiasaan yang Baik dalam Membaca}

Membaca yang baik diperlukan juga kebiasaan-kebiasaan yang baik pula. Menurut The Liang Gie yang dikutip oleh Slameto, agar siswa dapat membaca dengan efisien maka perlu adanya kebiasaan-kebiasaan yang baik pula. Kebiasaan-kebiasaan yang baik itu adalah sebagai berikut :

1. Memperhatikan kesehatan membaca .

2. Menyusun rencana atau jadwal

3. Membuat tanda-tanda atau catatan-catatan

4. Memanfaatkan perpustakaan

5. Membaca sungguh-sungguh semua buku-buku yang perlu sampai menguasai isinya

6. Membaca dengan konsentrasi penuh

\section{Faktor-faktor yang Mempengaruhi Minat Baca Siswa}

Menurut Farida Rahim ada beberapa faktor yang mempengaruhi minat serta kemampuan membaca seorang anak sebagai berikut :

1. Faktor fisiologis mencakup kesehatan fisik, pertimbangan neurologis, dan jenis kelamin. Kelelahan merupakan kondisi yang tidak menguntungkan bagi anak untuk belajar, terutama ketika membaca. Selain itu keterbatasan neurologis (misalnya berbagai cacat otak), gangguan pendengaran dan penglihatan akan memperlambat anak dalam belajar, terutama ketika membaca.

2. Faktor intelektual Secara umum, intelegensi anak tidak sepenuhnya mempengaruhi berhasil atau tidaknya anak dalam membaca, namun dari beberapa penelitian yang salah satunya dilakukan oleh Ehanski (1963) menunjukkan ada hubungan yang positif (tetapi rendah) antara IQ dengan rata-rata remedial membaca.

3. Faktor lingkungan juga mempengaruhi kemajuan kemampuan membaca anak. Faktor lingkungan mencakup latar belakang dan pengalaman anak di rumah. Dalam hal ini seorang anak tidak akan mengembangkan minatnya terhadap sesuatu terutama membaca jika mereka sebelumnya belum pernah mengalaminya. Selain itu, faktor ekonomi keluarga juga mempengaruhi minat baca seorang anak terutama dalam penyediaan buku bacaan.

4. Faktor psikologis

1) Motivasi Motivasi merupakan faktor kunci dalam membaca. Siswa yang mempunyai motivasi yang tinggi terhadap membaca, akan mempunyai minat yang tinggi pula terhadap kegiatan membaca.

2) Tingkat keterlibatan tekanan jika siswa merasa dirinya mempunyai beberapa tingkat pilihan dan kurang tekanan, minat membaca mereka mungkin akan lebih 
tinggi.

3) Kematangan sosio dan emosi seorang siswa harus mempunyai pengontrolan emosi pada tingkat tertentu. Kematangan sosio dan emosi lebih memudahkan anak dalam memusatkan perhatian pada bahan bacaan sehingga kemampuan anak dalam memahami bacaan akan meningkat.

\section{METODE PELAKSANAAN}

Metode pelaksanaan ini berupa kegiatan di lapangan yaitu dengan mengusung tema untuk meningkatkan minat baca anak usia dini pada PAUD Hasanuddin Majedi Banjarmasin kegiatan sosialisasi dalam membedah buku yang diminati banyak anakanak, Metode sosialisasi dilakukan dalam dua bagian utama, yaitu penyajian materi dan studi kasus- kasus. Adapun rangkaian kegiatan pengabdian masyarakat antara lain:

\section{Penyajian Materi}

Diawali dengan penjelasan tentang; Mengembangkan minat baca perlu ditumbuhkan sejak anak usia dini atau sejak mereka mulai bisa membaca. Dengan menumbuhkan minat baca sejak usia dini diharapkan budaya membaca masyarakat Indonesia akan lebih meningkat. Minat baca merupakan hal yang sangat penting bagi siswa taman kanak-kanak. Oleh sebab itu, harus dipupuk, ditumbuhkembangkan dan dibiasakan sejak dini. Dengan kegemaran membaca buku maka pada diri siswa aka tertanam untuk memiliki minat baca yang kuat. Minat baca yang telah dimiliki tidak hanya terdapat pada buku perpustakaan saja tetapi pada buku pelajaran sekolah juga. Membaca adalah suatu cara untuk mendapatkan informasi dari sesuatu yang ditulis. Membaca melibatkan pengenalan simbol yang menyusun sebuah bahasa. Membaca buku sangat penting, karena buku adalah jendela dunia dan gudangnya ilmu. Dengan membaca pula seseorang akan terbentuk kepribadiannya menjadi kepribadiannya menjadi baik. Meningkatnya keterampilan berusaha menengah kecil, untuk ibu yang tidak memiliki pekerjaan.

\section{Tanya Jawab}

Semua peserta diberikan kesempatan untuk bertanya tentang sesuatu yang belum jelas, baik yang telah disampaikan maupun hal-hal lain yang berkaitan dengan kegiatan tersebut .

\section{Pelaksanaan Kegiatan}

1. Nama dan Gelar Akademik : Hidayati Desy, S,Pd, M.Pd

2. Pangkat/ Golongan/ NIDN : 1109049201

3. Jabatan Fungsional : Tenaga Pengajar

4. Bidang Keahlian : Pendidikan Bahasa Indonesia

5. Fakultas/ Program studi : Akademi maritim nusantara Banjarmasin (KPN)

6. Waktu untuk kegiatan : 1 Hari

\section{HASIL DAN PEMBAHASAN}

Perkembangan ilmu pengetahuan dan teknologi menuntut terciptanya masyarakat yang gemar belajar. Proses belajar yang efektif antara lain dilakukan melalui membaca. Masyarakat yang gemar membaca memperoleh pengetahuan dan wawasan baru yang akan semakin meningkatkan kecerdasannya sehingga mereka lebih mampu menjawab tentang hidup pada masa-masa mendatang. Seperti halnya selogan "membaca adalah 
jendela dunia”. Maksud dari slogan tersebut bahwasanya dengan membaca akan menambah wawasan dan pengetahuan pada diri seseorang maka dari itu akan lebih baik jika anak-anak dibiasakan gemar membaca sejak usia dini. Anak-anak membaca tidak hanya dirumah tetapi bisa juga di perpustakaan, dengan adanya perpustakaan sekolah akan mempermudah anakanak dalam menyalurkan minat bacanya. Perpustakaan sekolah merupakan perangkat kelengkapan pendidikan dalam mencapai tujuan pendidikan di sekolah keberadaan perpustakaan di sekolah sangatlah penting membangun budaya membaca sejak dini. Anak yang mempunyai hobi membaca akan memiliki pengetahuan yang luas dan otaknya cerdas.

Sebagai orang tua harus memberikan motivasi agar anak menyukai kegiatan membaca buku sejak dini, karena perpustakaan sekolah merupakan perangkat kelengkapan pendidikan dalam mecapai tujuan pendidikan di sekolah, keberadaan perpustakaan sekolah sangatlah penting untuk menumbuhkan minat baca anak usia dini.

Dalam hal ini peran orang tua sangat membantu karena minat baca anak itu tumbuh dari kebiasaan orangtuanya atau dari lingkungannya. Melalui buku-buku itu anak dapat membuka pikirannya terhadap pengetahuan dan dapat meningkatkan kreativitas anak.

\section{Gambar 1.1}

Mengembangkan minat baca anak usia dini pada PAUD Hasanuddin Majedi melalui kegiatan literasi perpustakaan

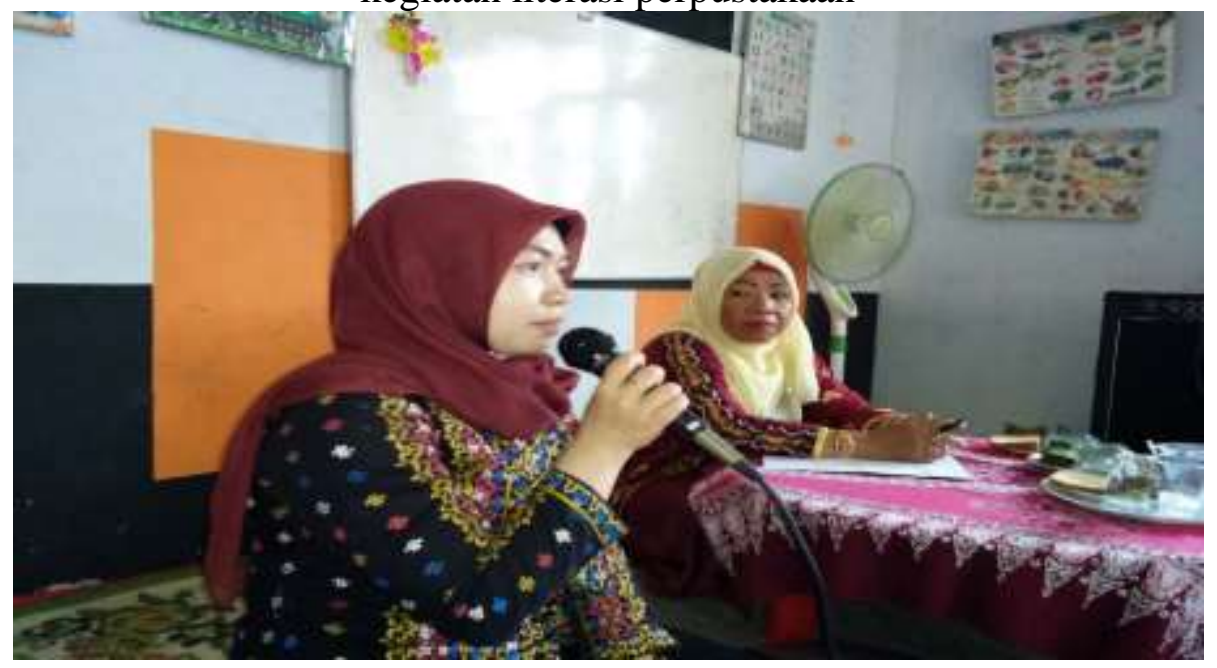

Sumber : Data Diolah februari 2020 
Gambar 1.2

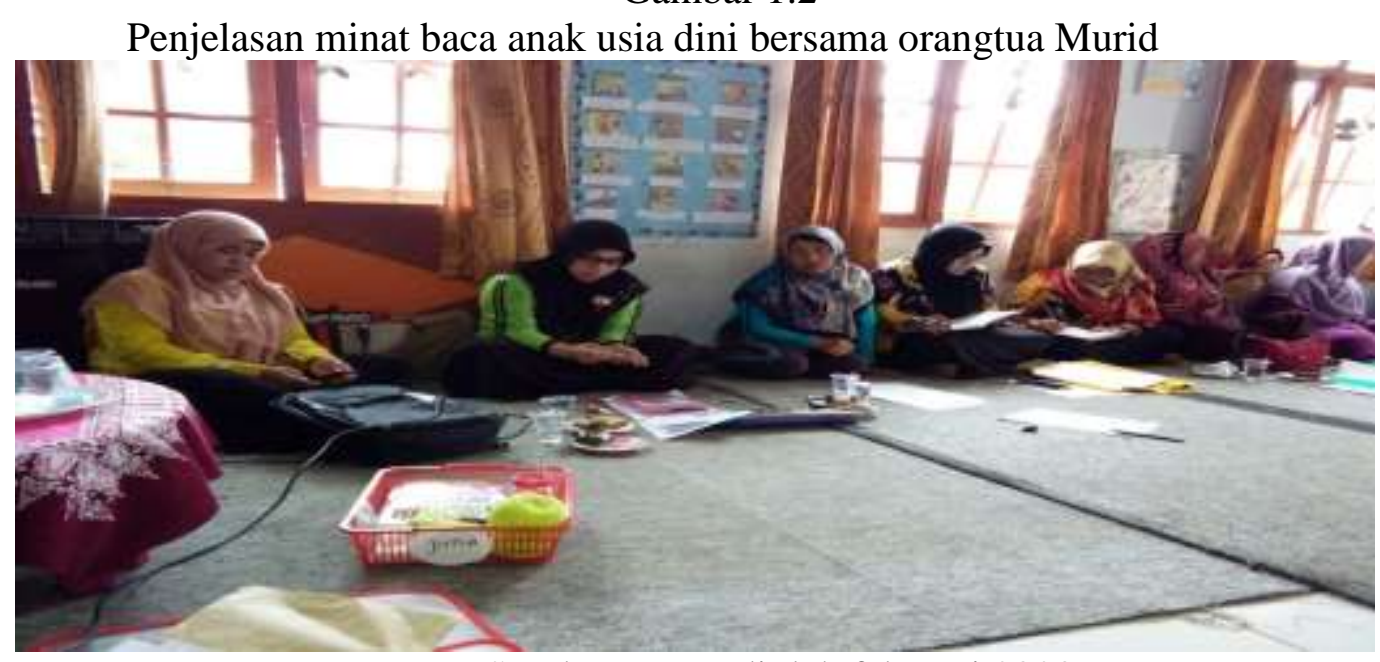

Sumber : Data diolah februari 2020

Diawali dengan pemberian arahan dan edukasi berupa minat baca anak usia dini pada PAUD Hasanuddin Majedi Banjarmasin melalui kegiatan literasi perpustakaan di kota Banjarmasin. Dari kegiatan ini beberapa pertanyaan yang dilontarkan peserta saat kegiatan berlangsung antara lain yaitu:

Kapan hal serupa kembali dalam minat baca anak usia dini pada PAUD Hasanuddin Majedi Banjarmasin melalui kegiatan literasi perpustakaan dikota Banjarmasin?

Kegiatan tersebut untuk menumbuhkan pengetahuan terkait Mengenalkan buku pada anak-anak merupakan tanggung jawab orang dewasa, khususnya orang tua. Anakanak tidak akan mencari atau menginginkan buku bacaan atas keinginannya sendiri karena anak belum mengerti manfaat membaca buku jika tidak ada teladan dari orang tuanya. Memberi dorongan dan pengertian akan pentingnya membaca buku perlu dilakukan orang tua agar anak tertarik dan mulai mencari buku. Pada dasarnya kecintaan anak pada kegiatan membaca akan berguna bagi pengembangan pribadi dan akademisnya. Namun demikian, minat dan kemampuan membaca tidak akan tumbuh secara otomatis, tapi harus melalui latihan dan pembiasaan. Artinya, apabila seorang ibu ingin anaknya mempunyai perilaku gemar membaca, kegiatan membaca inilah yang perlu dibiasakan sejak kecil.

\section{PENUTUP}

Kegiatan pengabdian pada masyarakat ini dapat disimpulkan sebagai berikut. Pertama, secara keseluruhan, mengembangkan minat baca anak usia dini melalui kegiatan literasi perpustakaan untuk meningkatkan minat baca anak usia dini pada PAUD Hasanuddin Majedi Banjarmasin melalui kegiatan literasi perpustakaan dikota Banjarmasin.termasuk dalam kategori dapat mengembangkan minat baca dengan adanya perpustakaan dan guru-gurunya juga berkompeten dalam mengembangkan minat baca melalui kegiatan literasi perpustakaan. Adanya indikator kebutuhan terhadap bacaan dengan indikator ini anak tumbuh dan berkembang menjadikan anak lebih menyukai buku, suka berdiskusi, saling bertukar cerita dan anak menjadi suka membaca. Tindakan untuk mencari bacaan, anak tertarik dengan buku untuk mencari bacaan dan tumbuh rasa ingin tahu yang tinggi. Rasa senang terhadap bacaan, anak suka membaca, bisa mengatur emosi, dan dapat meningkatkan rasa percaya diri. Ketertarikan terhadap bacaan, 
menjadikan anak suka membaca dan mempunyai imajenansi yang tinggi, suka menggambar.

Kedua, keinginan untuk selalu membaca, orang tua sangat berperan penting dalam mengembangkan minat baca untuk memberi dorongan dan semangat untuk membaca. Tindak lanjut menindaklanjuti bacaan, menindak lanjuti bacaan yang belum selesai dan anak mempunyai rasa ingin tahu yang tinggi. Keberhasilan minat baca sangat terlihat adanya kegiatan mengembangkan minat baca meningkat dan antusias anak terhadap buku dan bacaan.

Mengingat besarnya manfaat kegiatan pengabdian pada masyarakat ini, maka selanjutnya perlu:

1. Penambahan referensi buku lebih banyak lagi agar anak lebih banyak pilihan buku untuk dipinjam.

2. Cara guru dalam mengembangkan minat baca juga bagus selalu berikan cerita atau dongeng yang lebih mengispirasi agar anak lebih tertarik dengan buku ingin mencari buku dan menjadikan anak lebih percaya diri dan rasa suka atau senang terhadap bacaan semakin meningkat.

\section{DAFTAR PUSTAKA}

Arikunto, Suharsimi. 2013. Prosedur Penelitian suatu Pendekatan Praktek, Jakarta: Rineka Cipta.

Aunillah, Nurla Isna. 2015. Membentuk Karakter Anak Sejak Janin, Jakarta: FlashBooks. Bafadal, Ibrahim. 2005. Pengelolaan Perpustakaan Sekolah, Jakarta,PT: Bumu Aksara.

Bungin, Burhan. 2008. Penelitian kualitatif komunikatif, ekonomi, kebijakan publik, dan ilmu social lainnya, Jakarta: Kencana.

Dalman. 2014. Keterampilan Membaca, Jakarta: Rajawali Pres.

Darmono. 2010. Manajemen Dan Tata Kerja Perpustakaan Sekolah, Jakarta: PT Grasindo.

Desmita. 2009. Psikologi Perkembangan Peserta Didik, Bandung: Remaja Rosdakarya. Emzir. 2010. Metodologi Penelitian Kualitatif: Analisis Data, Jakarta: Rajawali Press.

Fathoni, Abdurahmat. 2006. Metodologi Penelitian \& Teknik Penyusunan Skripsi. Jakarta: PT Rineka Cipta Ibrahim, dan Nana Sujana. 2001. 